\title{
Effectiveness of Enteral Nutritional Therapy in the Healing Process of Pressure Ulcers: A Systematic Review*
}

\author{
Efetividade da terapia nutricional enteral no processo de \\ cicatrização das úlceras por pressão: revisão sistemática \\ Efectividad de la terapia de nutrición enteral en el proceso de \\ cicatrización de las úlceras por presión: revisión sistemática
}

Gisely Blanc ${ }^{1}$, Marineli Joaquim Meier², Janislei Giseli Dorociaki Stocco ${ }^{3}$, Hellen Roehrs ${ }^{4}$, Karla Crozeta ${ }^{5}$, Dulce Aparecida Barbosa ${ }^{6}$

\footnotetext{
* Extracted from the thesis " Efetividade da terapia nutricional enteral no processo de cicatrização das úlceras por pressão: revisão sistemática,"Universidade Federal do Paraná, 2013.

${ }^{1}$ Master's of Nursing, Graduate Program in Nursing, Universidade Federal do Paraná, Curitiba, PR, Brazil.

${ }^{2}$ Professor, Department of Nursing, Universidade Federal do Paraná, Curitiba, PR, Brazil.

${ }^{3}$ Doctoral Student, Graduate Nursing Program, Universidade Federal do Paraná, Curitiba, PR, Brazil.

${ }^{4}$ Professor, Department of Nursing, Universidade Federal do Paraná, Curitiba, PR, Brazil.

${ }^{5}$ Professor, Department of Nursing, Universidade Federal do Paraná, Curitiba, PR, Brazil.

${ }^{6}$ Associate Professor, Escola Paulista de Enfermagem, Universidade Federal de São Paulo, São Paulo, SP, Brazil.
}

\begin{abstract}
Objective: To evaluate the effectiveness of enteral nutritional therapy (ENT) in the healing process of pressure ulcers (PU) in adults and the elderly. Method: A systematic review whose studies were identified through the databases of Cochrane, MEDLINE/ PubMed, SciELO, LILACS, EMBASE, CINAHL, Web of Science, and manual searches. It included randomized clinical trials (RCTs) without delimiting the period or language of publication, which addressed adults and elderly patients with pressure ulcers in a comparative treatment of enteral nutritional therapy and placebo or between enteral nutritional therapy with different compositions and dosages. Results: We included ten studies that considered different interventions. It resulted in more pressure ulcers healed in the groups that received the intervention. The included studies were heterogeneous with regard to patients, the type of intervention, the sample and the follow-up period, all of which made meta-analysis impossible. Conclusion: Although the enteral nutritional therapy demonstrates a promotion of pressure ulcer healing, sufficient evidence to confirm the hypothesis was not found.
\end{abstract}

\section{DESCRIPTORS}

Pressure Ulcer; Nutrition Therapy; Wound Healing; Review. 


\section{INTRODUCTION}

A pressure ulcer $(\mathrm{PU})$ is a public health problem that affects sick people, the family and society. It is defined as "a damaged area located on the skin and underlying tissue caused by pressure, shear, friction, or a combination of ${ }^{(1) "}$. Its etiology has other contributing factors that are intrinsic to the subject such as nutrition, age, and comorbidities, among others ${ }^{(2)}$. Interventions imposed for its prevention and treatment interfere in health care quality ${ }^{(3)}$.

Age is considered a risk factor for PU, especially in patients aged 65 years or more. Failure of wound healing affects three to six million people at that age, and represents $85 \%$ of this occurrence ${ }^{(4)}$.

In Brazil, the concern with the PU became more evident with the publication of RDC No 36 , from July $25^{\text {th }} 2013$, which instituted actions to promote patient safety and quality improvement in health services. Prevention of PU was included in the patient safety plan for which strategies and actions for risk management must be developed ${ }^{(5)}$. A protocol was published for prevention that includes strategies for optimization of nutrition and hydration ${ }^{(6)}$.

Regarding nutrition, studies show a relationship between malnutrition and development of PU and delayed healing ${ }^{(7-8)}$. A study that classified patients as malnourished, at nutritional risk and well-nourished according to the Body Mass Index, found extremely poor nutritional status in patients with PU (39.5\% malnourished and $2.5 \%$ well-nourished), compared to patients without PU (16.6\% malnourished and 23.6\% well-nourished) (p $<0.001)^{(9)}$. A prospective study of high-risk and hospitalized patients identified malnutrition in $29 \%$ of patients upon admission and after four weeks $17 \%$ of these developed PU, however, the injury occurred in only $9 \%$ of patients who were not malnourished ${ }^{(10)}$.

In this sense, nutritional triage contributes to identifying the need for Enteral Nutrition Therapy (ENT) in order to provide calories, proteins, amino acids, vitamins and proper hydration for patients with PU. The nurse should be the one responsible for carrying out the nutritional triage and actions for implementing $\mathrm{ENT}^{(11-13)}$.

ENT uses specially formulated food (industrialized or not), exclusively or partially employed to replace or supplement the alimentation for the nutritional needs of the patient, and is engaged in the synthesis or maintenance of tissues, organs or systems ${ }^{(5,11)}$.

In order to prevent and treat PUs, many supplements were commercially developed for ENT (oral nutritional supplement and via nasogastric, nasoenteral/nasojejunal or percutaneous tube). These formulas are composed mainly of protein, arginine, glutamine, vitamin $\mathrm{C}$, zinc, iron and vitamin $\mathrm{E}^{(14)}$, and are classified according to the complexity of the nutrients in polymeric, oligomeric, and monomeric formulas, and also modular diets ${ }^{(15)}$.

Regarding the importance of adequate nutritional status for PU healing, it is necessary to evaluate the effectiveness of Nutritional Therapy (NT) as a treatment for PU. For both, research with the appropriate design on the theme as well as systematic reviews for presenting the best level of evidence for clinical decision making is indispensable.

A systematic review (SR) published in 2003 aimed at evaluating the effectiveness of enteral and parenteral nutrition for the prevention and treatment of PU included eight randomized controlled trials (RCTs), and noted that nutritional supplements reduced the number of new ulcers, but it was not possible to reach definitive conclusions about the effect of enteral and parenteral nutrition due to the heterogeneity of the studies ${ }^{(16)}$.

In another SR published in 2005 to verify the impact of enteral nutritional support on the incidence and healing of PUs, 15 studies were included and five were grouped into a meta-analysis of oral nutritional supplements or enteral tube feeding. The meta-analysis, $n=1.224$, of post-surgical chronically-hospitalized elderly patients showed that oral supplements were associated with a lower incidence of developing PU (odds ratio 0.75, 95\% CI [62-89]). As for wound healing, meta-analysis was not possible, however individual studies have shown favorable results with the use of high doses of protein supplements specialized for PU healing ${ }^{(17)}$.

In 2008, an SR evaluating treatments available for PU nutritional interventions included seven RCTs and the authors found that the protein supplementation promoted the healing of ulcers compared with placebo (Scale Healing average score 3.55 [4.66] vs. $3.22[4: 11], \mathrm{p}<0.05)$, but there is little evidence to justify routine use of ENT compared to the standard treatment for PU healing ${ }^{(18)}$.

While there have been SRs conducted involving nutrition in the prevention and treatment of PU, it was found that these were not restricted to ENT; extrapolating the research to other strategies and this does not achieve a wide search in the databases. Therefore, considering the urgency of new studies with methodological quality and that the SR makes it possible to obtain answers to clinical questions and safely incorporate new procedures to professional practice with scientific support ${ }^{(19)}$, a SR aimed at evaluating the effectiveness of Enteral Nutrition Therapy (ENT) in the healing process of Pressure Ulcers (PU) in adults and the elderly was proposed.

\section{METHOD}

It is a Systematic Review (SR), based on the Cocbrane Handbook for Systematic Revierws of the recommendations of Interventions proposed by the Cochrane Collaboration ${ }^{(20)}$. The SR differs from other review methods because it uses explicit procedures of systematic search and critical analysis to synthesize the literature on a particular issue, aiming to minimize biases and random error present in individual analyzes ${ }^{(19)}$.

To elaborate the research question, the acronym PI$\mathrm{CO}^{(20)}$ was employed ( $\mathrm{P}$ - population and problem; I - intervention; C - comparison; $\mathrm{O}$ - outcomes) in which: $\mathrm{P}$ Adults and the elderly with pressure ulcers; I - use of enteral nutritional therapy; $\mathrm{C}$ - Comparison without complement; or different formulas; $\mathrm{O}$ - Complete healing; Partial healing; Stability of the total area; reduction of exudate; reduction of devitalized tissues; treatment time for healing of pressure ulcers; and others. Thus, the research question was, "What is the effectiveness of enteral nutrition therapy in the $P U$ 
healing process in adults and the elderly?"

Inclusion criteria were randomized controlled trials without language restriction or publication date which evaluated the effect of ENT in the PU healing process in adults and elderly, hospitalized or at home, comparing treatment with ENT and placebo; ENT or of different compositions; or ENT with different dosages.

We excluded studies that involved other causes of wounds; were not limited to their ENT intervention (adopted another route of administration); or did not describe the formula used in ENT.

The primary endpoint was the overall healing of PU, and the secondary endpoints were partial healing of PU; stability of the area; reduction of exudate and devitalized tissue. The search took place from May to August 2013. The studies were identified through the following databases: Cochrane Central Register of Controlled Trials (CENTRAL) in The Cochrane Library, National Library of Medicine/NLM (MEDLINE)/PubMed, Scientific Electronic Library online (SciELO), Latin American and Caribbean Health Sciences (LILACS), Biomedical Database (EMBASE), Cumulative Index to Nursing and Allied Health Literature (CINAHL) and Web of Science. The procedure also included a manual search through consulting summaries of papers presented at conferences, reference articles and systematic reviews of identified RCTs, ECR registration databases and contact with researchers active in wound treatment area.

The search strategies were formulated according to the criteria and documentation for each database. We used Medical Subject Heading (MeSH) descriptors, descriptors in Health Sciences (MeSH), and terms related to the research problem (pressure ulcers), intervention (enteral nutrition therapy) and study design (randomized controlled trial), combined with boolean operators (AND and OR) and truncation symbols.

Chart 1 shows the search strategy adopted in the MEDLINE via PubMed, which was adapted for the other analyzed databases.

For inclusion, the abstracts of the identified studies were blindly and independently assessed by two reviewers who applied the eligibility criteria and selected the relevant studies; in case of disagreement, a third reviewer was requested. In the first consensus meeting the selected studies were evaluated in full with application of eligibility criteria; and then in the second consensus meeting, the studies to be included and excluded from the review were defined. The degree of agreement between reviewers was assessed by measuring Kappa ${ }^{(20)}$ using the STATA ${ }^{\oplus} 9.7$ software. The Kappa assesses the interobserver agreement and ranges from 1 (complete agreement) to -1 (complete disagreement) ${ }^{(21)}$.

For data extraction, a form ${ }^{(22)}$ was adopted which included: identification of the study (title, journal, year of publication, volume and number), method, characteristics of participants and intervention, outcome, ethical aspects, financing and opinion of the reviewer.

The methodological quality of the studies was performed using the Cochrane Collaboration tool for assessing the risk of bias in randomized clinical trials available in Review
Manager version 5.1.0 program, in which the studies were judged as 'low risk of bias,' 'high risk bias' and 'uncertain/ unclear risk of bias' to six domains/areas: random sequence generation, allocation concealment, blinding of participants and personnel, blinding of outcome assessment, incomplete outcome data and selective outcome ${ }^{(20)}$.

Due to the heterogeneity of the studies, the data were descriptively grouped and analyzed for outcomes.

There was no conflict of interest in conducting this review, nor was any funding provided for the study.

Chart 1 - Search strategy in MEDLINE/PubMed database - Curitiba, PR, 2013.

\#1 (c(c(c((“Pressure Ulcer”[MeSH Terms] OR Pressure Ulcers[Title/ Abstract]) OR Ulcers, Pressure[Title/Abstract]) OR Bedsore[Title/ Abstract]) OR Bedsores[Title/Abstract]) OR Pressure Sore[Title/ Abstract]) OR Pressure Sores[Title/Abstract]) OR Bed Sores[Title/

Abstract]) OR Bed Sore[Title/Abstract]) OR Decubitus Ulcer[Title/ Abstract]) OR Decubitus Ulcers[Title/Abstract]

\#2 "Diet Therapy"[MeSH Terms] OR Diet Therapies[Title/Abstract] OR "dietary supplements"[MeSH Terms] OR Dietary Supplement[Title/Abstract] OR Food Supplementation[Title/ Abstract] OR Dietary Supplementation[Title/Abstract] OR Dietary Supplementations[Title/Abstract] OR Supplemented Food[Title/Abstract] OR Supplemented Foods[Title/Abstract] OR Food Supplements[Title/Abstract] OR Food Supplement[Title/ Abstract] OR "enteral nutrition" [MeSH Terms] OR Enteral Feeding[Title/Abstract] OR Tube Feeding[Title/Abstract] OR "food, formulated"[MeSH Terms] OR Formulated Food[Title/Abstract] OR Formulated Foods[Title/Abstract] OR Synthetic Diet[Title/ Abstract] OR Dietary Formulations[Title/Abstract] OR Dietary Formulation[Title/Abstract] OR Chemically Defined Diet[Title/ Abstract] OR Chemically Defined Diets[Title/Abstract] OR Elemental Diet[Title/Abstract] OR Elemental Diets[Title/Abstract] OR ("nutritional support" [MeSH Terms] OR "nutrition therapy" [MeSH Terms]) OR Medical Nutrition Therapy[Title/Abstract] OR "nutritional support" [MeSH Terms] OR Artificial Feeding[Title/Abstract]

\#3 (c(c((Clinical Trial [Publication Type]) OR Randomized[Title/Abstract]) OR Placebo[Title/Abstract]) OR Clinical Trial as Topic [MeSH Terms]) OR Randomly[Title/Abstract]) OR Trial[Title/Abstract]) OR Groups[Title/Abstract])

\#1 AND \#2 AND \#3

\section{RESULTS}

432 studies were identified, of which 66 were in MEDLINE/PUBMED, 100 in EMBASE, 58 in CENTRAL, 124 in Web of Science, 69 in CINAHL, zero/none in SciELO or LILACS, and 15 in the manual search. Of these, 156 were duplicates and 244 did not meet the inclusion criteria. Thus, we evaluated 32 studies in full, and after an independent review by two reviewers, ten studies were included in this review, as shown in Figure 2. The opinion of the third reviewer for consensus of the included studies was requested. The Kappa index showed significant agreement 0.939 ( $\mathrm{p}<0.001$ and $95 \% \mathrm{CI}$ ).

In the assessment of methodological quality of the studies, only two had low risk of bias for all assessed areas (E32, E90) and one for five areas (E5). Two classified with two areas as high risk of bias (E419, E424) and two with one (E420, E10). In eight studies there were at least one classified area in uncertain risk of bias (E5, E10, E412, E418: $\mathrm{E} 419, \mathrm{E} 424, \mathrm{E} 425, \mathrm{E} 426)$, which shows a lack of detail in the description of the methodology of these studies and prevents a proper analysis as to quality. Figure 2 gives a review of studies for each area individually. 


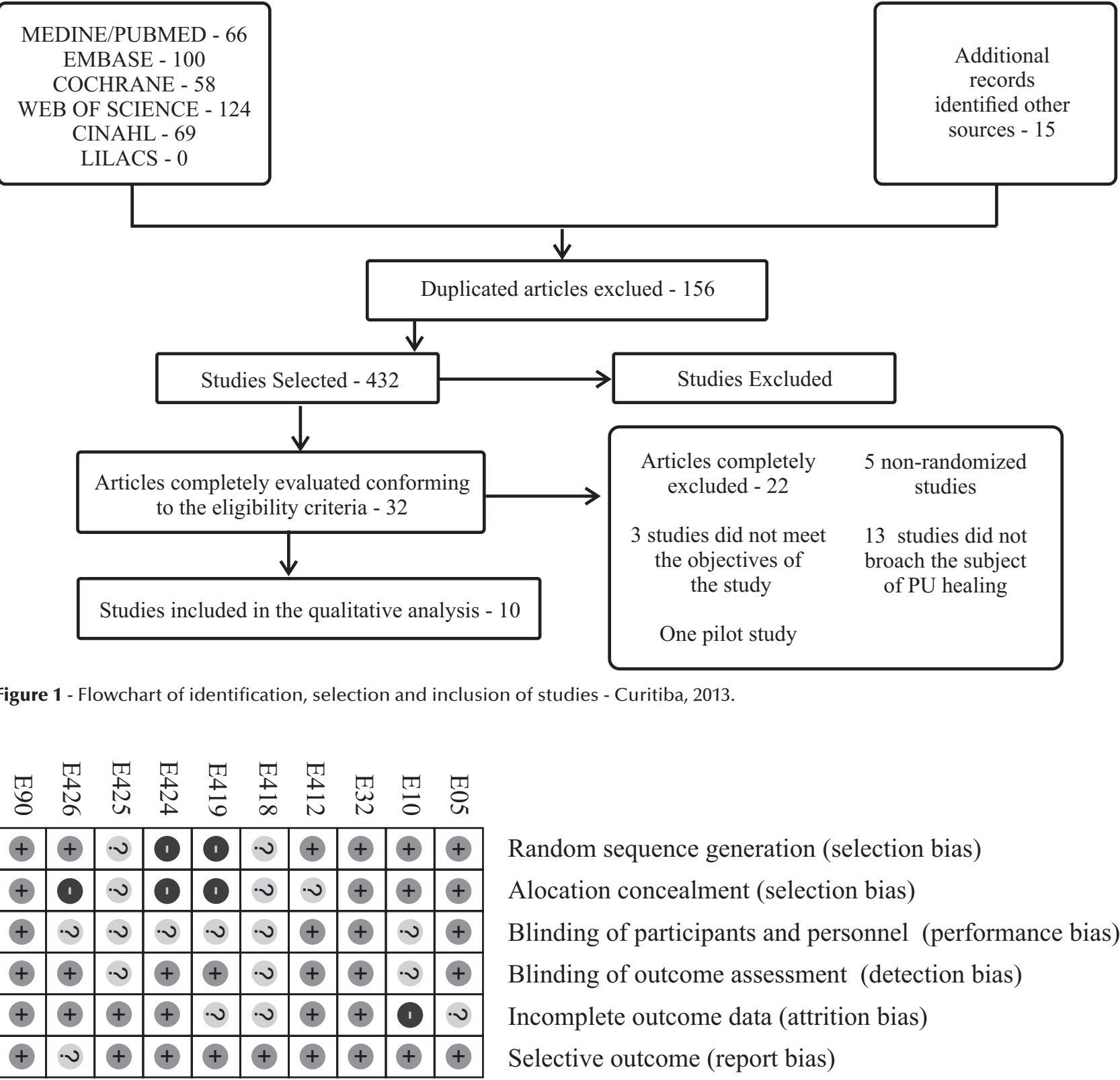

Legend: + 'low risk of bias' (low risk of bias); - High risk of bias' (high risk of bias); ? 'uncertain risk of bias' (unclear risk of bias).

Figure 2 - Individual assessment of the methodological quality of the studies included in the systematic review - Curitiba, PR, 2013.

Chart 2 presents selected studies and related references, year of publication, country, design and number of patients. Chart 3 presents the list of studies as the intervention and the number of participants in the experimental group and control, valuation and follow-up. It is noted that the opera- tions contemplated supplements such as arginine, vitamin $\mathrm{C}$, collagen, ornithine alpha-ketoglutarate (OKG), zinc sulfate, hydrolyzed collagen and mixed nutritional supplements. Only two studies (E412, E419) had the same intervention (vitamin $\mathrm{C}$ ).

Chart 2 - Selected studies according to the reference year, country, design and number of patients - Curitiba, 2013.

\begin{tabular}{|c|c|c|c|}
\hline Study & Reference & Year/Country & Design/number of patients \\
\hline E5 & $\begin{array}{c}\text { Leigh B, Desneves K, Rafferty J, Pearce L, King S, Woodward MC, et al. } \\
\text { The effect of different doses of an arginine-containing supplement on the } \\
\text { healing of Pressure ulcers. J Wound Care. 2012; 21(3):150-6. }\end{array}$ & $\begin{array}{c}2012 \\
\text { Australia }\end{array}$ & $\begin{array}{c}\text { Randomized Clinical } \\
\text { Trial /n=23 }\end{array}$ \\
\hline E10 & $\begin{array}{l}\text { Ohura T, Nakajo T, Okada S, Omura K, Adachi K. Evaluation of effects of } \\
\text { nutrition intervention on healing of pressure ulcers and nutritional states } \\
\text { (randomized controlled trial). Wound Repair Regen. 2011;9(3):330-6. }\end{array}$ & $\begin{array}{c}2011 \\
\text { Japan }\end{array}$ & $\begin{array}{c}\text { Multicenter, Randomized } \\
\text { Clinical Trial /n=30 }\end{array}$ \\
\hline
\end{tabular}


...continuation

\begin{tabular}{|c|c|c|c|}
\hline Study & Reference & Year/Country & Design/number of patients \\
\hline E32 & $\begin{array}{c}\text { Lee SK, Posthauer ME, Dorner B, Redovian V, Maloney MJ. Pressure } \\
\text { ulcer healing with a concentrated, fortified, collagen protein hydroly- } \\
\text { sate supplement: a randomized controlled trial. Adv Skin Wound Care. } \\
\text { 2006;19(2):92-6. }\end{array}$ & $\begin{array}{l}2006 \\
\text { United States of } \\
\text { America }\end{array}$ & $\begin{array}{l}\text { Multicenter, Controlled, } \\
\text { Randomized Clinical Trial } / \mathrm{n}=89\end{array}$ \\
\hline E90 & $\begin{array}{c}\text { Meaume S, Kerihuel JC, Constans T, Teot L, Lerebours E, Kern J, et al. Ef- } \\
\text { ficacy and safety of ornithine alpha-ketoglutarate in heel pressure ulcers } \\
\text { in elderly patients: results of a randomized controlled trial. J Nutr Health } \\
\text { Aging. 2009; 13(7):623-30. }\end{array}$ & $\begin{array}{l}2009 \\
\text { Bulgaria, France, } \\
\text { Germany, Italy, } \\
\text { Romania, Spain }\end{array}$ & $\begin{array}{l}\text { Multicenter, Randomized Clinical } \\
\text { Trial } / \mathrm{n}=160\end{array}$ \\
\hline E412 & $\begin{array}{l}\text { Riet GT, Kessels AG, Knipschild P. Randomised clinical trial of ultrasound } \\
\text { treatment for pressure ulcers. BMJ. 1995; 310(6986):1040-1. }\end{array}$ & $\begin{array}{l}1995 \\
\text { Holland }\end{array}$ & $\begin{array}{l}\text { Multicenter, Blind, Randomized } \\
\text { Clinical Trial } / \mathrm{n}=88\end{array}$ \\
\hline E418 & $\begin{array}{l}\text { Norris JR, Reynolds RE. The effect of oral zinc sulfate therapy on decubi- } \\
\text { tus ulcers. J Am Geriatr Soc. } 1971 ; 19(9): 793-7 \text {. }\end{array}$ & $\begin{array}{l}1971 \\
\text { United States of } \\
\quad \text { America }\end{array}$ & $\begin{array}{l}\text { Randomized Clinical Trial } \\
\quad \text { Crossover } / \mathrm{n}=14\end{array}$ \\
\hline E419 & $\begin{array}{c}\text { Taylor TV, Rimmer S, Day B, Butcher J, Dymock IW. Ascorbic } \\
\text { acid supplementation in the treatment of pressure-sores. Lancet. } \\
1974 ; 304(7880): 544-6 .\end{array}$ & $\begin{array}{l}1974 \\
\text { United States of } \\
\text { America }\end{array}$ & $\begin{array}{l}\text { Double-Blind, Controlled, } \\
\text { Randomized Clinical Trial } / \mathrm{n}=20\end{array}$ \\
\hline E424 & $\begin{array}{l}\text { Desneves KJ, Todorovic BE, Cassar A, Crowe TC. Treatment with supple- } \\
\text { mentary arginine, vitamin C and zinc in patients with pressure ulcers: a } \\
\text { randomised controlled trial. Clin Nutr. 2005; 24(6):979-87. }\end{array}$ & $\begin{array}{c}2005 \\
\text { Australia }\end{array}$ & Randomized Clinical Trial $/ \mathrm{n}=16$ \\
\hline E425 & $\begin{array}{c}\text { Van Anholt RD, Sobotka L, Meijer EP, Heyman H, Groen HW, Topinková } \\
\text { E, Van Leen M, et al. Specific nutritional support accelerates pressure } \\
\text { ulcer healing and reduces wound care intensity in non-malnourished pa- } \\
\text { tients. Nutrition. 2010; 26(9):867-72. }\end{array}$ & $\begin{array}{c}2010 \\
\text { Czech Republic, } \\
\text { Belgium, } \\
\text { Holland, } \\
\text { Curacao }\end{array}$ & $\begin{array}{l}\text { Multicenter, Randomized Clinical } \\
\text { Trial } / n=43\end{array}$ \\
\hline E426 & $\begin{array}{c}\text { Cereda E, Gini A, Pedrolli C, Vanotti A. Disease-Specific, Versus Standard, } \\
\text { Nutritional Support for the Treatment of Pressure Ulcers in Institutional- } \\
\text { ized Older Adults: a randomized controlled trial. Am Geriatr Soc. 2009; } \\
57(8): 1395-402 .\end{array}$ & $\begin{array}{l}2009 \\
\text { Italy }\end{array}$ & $\begin{array}{l}\text { Controlled, Randomized Clinical } \\
\text { Trial } / \mathrm{n}=38\end{array}$ \\
\hline
\end{tabular}

Chart 3 - Selected studies according to the intervention in the experimental and control groups, number of participants in the experimental group and control, evaluation and follow-up - Curitiba, 2013.

\begin{tabular}{|c|c|c|c|c|c|}
\hline Study & Intervention & $\begin{array}{l}\text { Experiment } \\
(\mathrm{N})\end{array}$ & $\begin{array}{c}\text { Control } \\
(\mathrm{N})\end{array}$ & $\begin{array}{l}\text { Evaluation } \\
\text { Method }\end{array}$ & Follow-up time \\
\hline E10 & $\begin{array}{l}\text { Mixed nutritional supplements } \\
\text { Specialized formula containing protein, carbohydrates, fats and } \\
\text { micronutrients in calculated amount based on energy expendi- } \\
\text { ture and stress factor vs specialized formula containing protein, } \\
\text { carbohydrates, fats and micronutrients maintaining normal } \\
\text { caloric intake; }\end{array}$ & 21 & 29 & DESIGN scale; & 12 weeks \\
\hline E424 & $\begin{array}{l}\text { Standard hospital diet (diet A) vs standard hospital diet and } \\
\text { specialized formula with high protein content (diet B) vs stan- } \\
\text { dard hospital diet and specialized formula with high protein, } \\
\text { arginine, zinc and vitamin C (diet C); }\end{array}$ & $\begin{array}{l}\text { Diet } B-5 \\
\text { Diet } C-5\end{array}$ & Diet A - 6 & PUSH tool; & 3 weeks \\
\hline E425 & $\begin{array}{l}\text { Specialized formula with high energy content and enriched } \\
\text { with arginine, vitamin C, vitamin A, vitamin E, carotenoids, } \\
\text { zinc, selenium, copper, and folic acid vs placebo; }\end{array}$ & 22 & 21 & PUSH tool; & 8 weeks \\
\hline E426 & $\begin{array}{l}\text { Specialized formula enriched with arginine, zinc and vitamin C } \\
\text { vs standard hospital diet or standard enteral formula; }\end{array}$ & 13 & 15 & PUSH tool; & 12 weeks \\
\hline E5 & $\begin{array}{c}\text { Arginine } \\
4.5 \mathrm{~g} \text { of arginine vs } 9 \mathrm{~g} \text { of arginine; }\end{array}$ & 12 & 11 & PUSH tool; & 3 weeks \\
\hline E32 & $\begin{array}{l}\text { Hydrolyzed collagen } \\
\text { Hydrolyzed collagen vs Placebo; }\end{array}$ & 44 & 27 & PUSH tool; & 8 weeks \\
\hline E90 & $\begin{array}{l}\text { Ornithine alpha-ketoglutarate } \\
\text { Ornithine alpha-ketoglutarate (OKG) vs Placebo; }\end{array}$ & 85 & 75 & $\begin{array}{l}\text { Verification of } \\
\text { the area; }\end{array}$ & 6 weeks \\
\hline E412 & $\begin{array}{c}\text { Vitamin C } \\
\text { Vitamin C (500 mg two times per day) vs Vitamin C (10 mg two } \\
\text { times per day); }\end{array}$ & 38 & 29 & $\begin{array}{l}\text { Verification of } \\
\text { the area; and } \\
\text { photography; }\end{array}$ & 12 weeks \\
\hline E419 & $\begin{array}{l}\text { Vitamin C (500 mg two times per day) vs Placebo (two times } \\
\text { per day); }\end{array}$ & 10 & 10 & $\begin{array}{l}\text { Subjective } \\
\text { evaluation of } \\
\text { a researcher; } \\
\text { Verification of } \\
\text { the area; and } \\
\text { photography; }\end{array}$ & 4 weeks \\
\hline
\end{tabular}

continued... 
..continuation

\begin{tabular}{|c|c|c|c|c|c|}
\hline Study & Intervention & $\begin{array}{c}\text { Experiment } \\
(\mathbf{N})\end{array}$ & $\begin{array}{c}\text { Control } \\
\text { (N) }\end{array}$ & $\begin{array}{c}\text { Evaluation } \\
\text { Method }\end{array}$ & Follow-up time \\
\hline E418 & $\begin{array}{c}\text { Zinc Sulfate } \\
\text { Zinc sulfate vs Placebo; }\end{array}$ & 10 & 10 & $\begin{array}{c}\text { Verification } \\
\text { of the volume } \\
\text { of the lesion } \\
\text { through } \\
\text { alginate } \\
\text { (jeltrate); }\end{array}$ & $\begin{array}{c}24 \text { weeks } \\
\text { (permutation with } \\
12 \text { ) }\end{array}$ \\
\hline
\end{tabular}

Four studies (E10, E424, E425, E426) evaluated the use of mixed nutritional supplements. In the study E10, interaction between the two groups (intervention and control) as the size of the PU and the intervention period was significant $(\mathrm{p}<0.001)$. There was a significant reduction in wound size from the first day of the intervention period ( $p$ $=0.05$ ). The E424 study that evaluated the diets A, B and C, obtained that: Diet $\mathbf{C}$ showed a significant improvement of the initial PUSH tool score $(9.4 \pm 1.2)$; and the PUSH tool score in the third week was significantly lower compared to diets $\mathrm{A}$ and $\mathrm{B}(7.0 \pm 1.5$ and $6.0 \pm 1.2, \mathrm{p}<0.05)$. The patients showed an approximate 2.5 times greater improvement in healing of the PU after three weeks in comparison with the other two groups. Diet A (control) showed a slight improvement in the healing of PU in the third week $(8.7 \pm$ 1.0 vs. $7.0 \pm 1.5$; Week 0 and 3 , respectively; $\mathrm{p}<0.05$ ), and for Diet $\mathbf{B}$ there were no significant changes in PUSH tool score in the three weeks.

In the study E425, reduction in the size of the PU in the experimental group differed significantly from the control group during the eight-week period $(\mathrm{p}=0.006$, treatment by time, $\mathrm{p}=0.016$, treatment by time $\mathrm{e}^{2}$, repeated-measures mixed models [RMMM]). PU in the experimental group were significantly lower compared with the initial assessment from the third week $(p=0.019)$ and in the following weeks $(\mathrm{p}=0.012)$. In the control group, the PU were significantly lower compared with the initial assessment from the fifth week $(\mathrm{p}=0.019)$, and in subsequent weeks $(\mathrm{p}=0.008)$. The PUSH tool score improved significantly in the experimental group compared with the control group ( $\mathrm{p}=0.011$, treatment by time, $p=0.033$, treatment by time $\left.{ }^{2}, R M M M\right)$. The types of tissues differed significantly between treatments after four weeks, there were fewer PU identified with 'granulation tissue' or 'necrotic tissue' and more PU identified as 'closed' or 'epithelial tissue' in the experimental group compared to the control group $(\mathrm{p}=0.037)$, demonstrating good progress of healing and the presence of complete healing of the lesions. The PUSH tool instrument subscores related to the size of the PU and amount of exudate did not differ significantly between groups. However, the decrease in the number of dressings (experimental group) differed significantly from the control group throughout the period of eight weeks ( $p=0.003$, treatment by time; $p=0.045$, treatment by time ${ }^{2}$ RMMM, post hoc). Thus, it is inferred that the general health condition of the PU improved; for instance the exudate and presence of devitalized tissues.

The differences between the interventions in E426 study became statistically significant in the PUSH tool score in week $12(\mathrm{p}<0.05)$ and PU area in week $8(\mathrm{p}<0.05)$. The experimental group showed a significantly greater reduction in average with regard to the area of PU ( $57 \%$ vs. $33 \%$ at 8 weeks, $\mathrm{p}<0.02 ; 72 \%$ vs $45 \%$ at 12 weeks, $\mathrm{p}<0.005$ ). The provision of adequate amounts of energy and protein was shown to be effective in improving the healing of PU $(\mathrm{p}<0.001)$ for both groups.

The E5 study evaluated the use of arginine in the healing of PU and obtained a significant difference in PUSH tool score declining over time $(\mathrm{p}<0.001)$. There was no difference in healing rates between the groups ( $\mathrm{p}=0.991)$.

The E32 study evaluated the hydrolyzed collagen and identified that changing the PUSH tool score in eight weeks was $3.22 \pm 4.11$ in the control group and $3.55 \pm 4.66$ $(\mathrm{p}<0.05)$ in the experimental group. The PUSH tool scores decreased in all patients during the intervention period, however the experimental group had approximately twice the healing rate compared to the control group. The experimental group had greater reduction in PUSH tool scores compared to the control group ( $60 \%$ vs $48 \%, \mathrm{p}<0.05)$.

The ornithine alpha-ketoglutarate was evaluated by E90 studies and the PU subgroup with area $\leq \mathbf{8} \mathbf{c m}^{2}$ showed an absolute decrease in PU area in the sixth week significantly higher in the experimental group compared with the control group $\left(-2.3 \pm 4.2 \mathrm{~cm}^{2}\right.$ vs. $\left.-1.7 \pm 1.7 \mathrm{~cm}^{2}, \mathrm{p}=0.006\right)$. There was a tendency to a higher proportion of wounds that reached a higher regression to $90 \%$ in six weeks in the experimental group (23.4\% vs $13.0 \%)(\mathrm{OR}=0.49 ; 95 \% \mathrm{CI}$ [0.16 to 1.46$]$. The healing rate was higher in the experimental group compared to the control group $(-0.07 \pm 0.11$ $\mathrm{cm}^{2} /$ day vs. $0.04 \pm 0.08 \mathrm{~cm}^{2} /$ day; $\left.p=0.007\right)$. In subgroup area $>\mathbf{8} \mathbf{~ c m}^{2}$ there were no differences between the groups regarding the absolute decrease in the area, proportion of regression and PU healing rate. There was no difference in healing rates.

Two studies assessed vitamin C (E412, E419). The E412 study in the analysis by intention to treat (ITT), the absolute healing rate in the experimental group was 0.21 and $0.27 \mathrm{~cm}^{2} /$ week in the control group $(90 \% \mathrm{CI})$. The average reduction in the volume of PU was $0 \mathrm{ml} /$ week in the experimental group and $0.20 \mathrm{ml} /$ week in the control group $(90 \% \mathrm{CI})$. The average 'clinical change' (healing rate, reduced surface and volume) was scored on a scale from -100 to $+100 \%$, and the experimental group showed improvements of $17.89 \%$ per week and $26.08 \%$ per week in the control group. In the per-protocol analysis, 67 patients were included; the absolute healing rate in the experimental group ( $\mathrm{n}=35$ ) was 0.23 and was $0.27 \mathrm{~cm}^{2} /$ week in the control group $(n=28)(90 \% \mathrm{CI})$. The average reduction in the volume of PU was $0.05 \mathrm{ml} /$ week in the experimental group 
and $0.11 \mathrm{ml} /$ week in the control group $(90 \% \mathrm{CI})$. The average 'clinical change' in the experimental group was $18.79 \%$ per week and $29.50 \%$ per week in the control group.

In the E419 study, the experimental group showed a significant reduction in the PU area of $84 \%(\mathrm{p}<0.005)$, compared to $42.7 \%(\mathrm{p}<0.001)$ in the control group. The mean healing rates were $2.47 \mathrm{~cm}^{2}$ and $1.45 \mathrm{~cm}^{2}$ per week in the treated and untreated groups, respectively.

Zinc sulfate was assessed in the E418 study. For the ten participants who received the intervention, there was a change in the PU with regard to the average volume of 10 $\mathrm{ml}( \pm 9 \mathrm{ml})$, the ten patients who had received placebo had a change in average volume of $6.0 \mathrm{~mL}(17.5 \mathrm{ml} \pm)$, the results were not statistically significant.

\section{DISCUSSION}

Considering that proper nutrition is related to the healing process, the objective of this SR was to evaluate the effectiveness of ENT as a treatment in the PU healing process for adults and the elderly. For this outcome, the results of the included studies show that ENT helps the healing of PU, but sufficient evidence was not found to confirm this finding.

553 patients were randomized from selected studies, and of these 488 were included in the analyzes of the data.

Regarding the 'complete healing of PU', five studies reported that $39 \mathrm{PU}$ achieved this outcome (E10, E90, $\mathrm{E} 425, \mathrm{E} 426, \mathrm{E} 419)$. A greater proportion of $\mathrm{PU}$ healed in the experimental groups (61.5\%). For the subgroup 'mixed nutritional supplements' (E10; E425; E426) there were 16 PU healed in experimental groups $(28.5 \% ; \mathrm{N}=56)$ and 9 in control (13\%, $\mathrm{N}=65)$, tracking time of 8 to 12 weeks.

This agrees with the finding of this study ${ }^{(23)}$, an open multicenter trial which included 245 patients and evaluated the effects of mixed nutritional supplements (protein, arginine, vitamin $\mathrm{C}$, vitamin $\mathrm{E}$, and other micronutrients - Cubitan $\left.{ }^{\circledR}\right)$, and obtained 65 PU (27\%) healed in nine weeks. The systematic review ${ }^{(24)}$ used the following terms for limiting the use of outcomes: 'reduction in wound size' and 'healing rate' as a substitute for 'complete healing' for the included studies, and the lack of homogeneity in the outcomes made it difficult to compare studies.

As for the outcome 'partial healing' for the subgroup 'mixed nutritional supplements', the groups that received the intervention showed a decrease in depth and area of the lesion, as well as improved healing rates compared to the control groups. It is inferred that ENT enriched with proteins and micronutrients favor the PU healing process (E10, E424, E425, E426). In line with this finding, a study ${ }^{(23)}$ found a significant reduction in the area of ulcers (1580 \pm $3743 \mathrm{~mm}^{2}$ to $743 \mathrm{~mm}^{2} \pm 1809$ ), representing $53 \%$ reduction in nine weeks $(\mathrm{p}<0.0001)$. A prospective study ${ }^{(25)}$ conducted with 39 patients which used a mixed nutritional supplement (supplement rich in protein, enriched with arginine, vitamin $\mathrm{C}$ and zinc), and after three weeks of intervention showed significant reduction in the area of PU $\left(23.6 \mathrm{~cm}^{2}\right.$ to $\left.19.2 \mathrm{~cm}^{2}\right)(\mathrm{p}<0.001)$, representing a reduction of $29 \%$. Still, national guideline recommends nutrition therapy for
PU patients using nutrient immune-modulating formulas and higher protein content in the treating patients with $\mathrm{PU}$, with a high degree of recommendation and strength of evidence $(\mathrm{A})^{(26)}$.

For the 'arginine' subgroup, only one study evaluated this nutrient alone. There were no significant differences in the healing rate between the experimental and control groups, so it is suggested that a dose of $4.5 \mathrm{~g}$ of arginine per day can promote effective similar healing compared to a dose of $9 \mathrm{~g}$ (E5).It is noteworthy that of the included studies, three had arginine in the formula compositions (E424, E425, E426). An observational study ${ }^{(27)}$ evaluated the rate and the time for PU healing in 18 participants who received nutritional therapy with $9 \mathrm{~g}$ of arginine $\left(\right.$ Arginaid $^{\circledR}$, Nestle Nutrition $^{\circledR}$ ) compared to a historical control with 17 participants. We identified a total of $26 \mathrm{PU}$ healed in the historical control group and $30 \mathrm{PU}$ in the 18 patients in the experimental group. In the experimental group, the healing time was found to be twice as fast compared to the control (10.5 \pm 1.3 weeks vs $21 \pm 3.7$ weeks; $p=0.006$ ). Therefore, this study suggests the benefit of supplementation with $9 \mathrm{~g}$ of arginine for PU healing.

The results deviated for the 'vitamin C' subgroup. Given the heterogeneity of the included studies, it is concluded that there is no evidence on the benefits of vitamin $\mathrm{C}$ supplementation in the healing of PU (E412, E419). To confirm these findings, four other SRs that evaluated the effects of vitamin $\mathrm{C}$ supplementation in PU healing were included in the same studies of this review and concluded that due to the scarcity of scientific production and methodological rigor, the role of vitamin $\mathrm{C}$ remains uncertain in the healing of $\mathrm{PU}{ }^{(16,18,24,)}$. It is noteworthy that four other studies included in this review had vitamin $\mathrm{C}$ in the compositions of formulas (E10; E424: E425, E426).

The patients who received the 'zinc sulfate' intervention showed a reduction in the volume of the lesion, however there was no statistical significance and only three patients completed the study (E418). Corroborating this data, six RCTs were included in a $\mathrm{SR}^{(28)}$ in order to determine the effectiveness of zinc sulfate supplementation promote the healing of venous and arterial ulcers, noting that there is no evidence to say that zinc sulfate supplementation promotes healing.

A critical review ${ }^{(29)}$ on the effects of zinc supplementation in wound healing was conducted in the scientific literature and found that zinc significantly participates in the healing process, however there is evidence to support the indication of supplementation. The included studies were considered old, with small samples, short follow-up, high rate of follow-up losses, and low methodological quality. Thus, we highlight the need for studies with rigorous methodology.

Regarding the use of 'mixed nutritional supplements', although there is no evidence that supplementation with vitamins and minerals assist in the healing of PU, supplementation is recommended when there is suspicion of deficiencies ${ }^{(3)}$.

For the 'ornithine alpha-ketoglutarate', there were only statistical differences for the subgroup $\leq 8 \mathrm{~cm}^{2}$, the 
experimental group showed greater reduction in total area compared to the control. The study suggests that supplementation with OKG has benefits in reducing the PU area with an area less than or equal to $8 \mathrm{~cm}^{2}$, accelerating the healing process (E90). This data corroborates the RCT with 47 participants which examined the effectiveness of OKG compared with isonitrogenous control in the healing of severely burned patients. It was found that the healing time of wounds in patients receiving $\mathrm{OKG}$ was lower compared to the control $(60 \pm 7 \text { vs } 90 \pm 12 \text { days; } \mathrm{p}<0.05)^{(30)}$.

For 'hydrolyzed collagen', the experimental group had approximately twice the healing rate compared to the control group and obtained greater reduction in PUSH tool score in eight weeks ( $60 \%$ vs $48 \%, \mathrm{p}<0.05)$. The study suggests that supplementation with hydrolyzed collagen promotes PU healing (E32). Other studies that have evaluated the effects of ENT with hydrolyzed collagen in PU and other types of wounds were not identified; the authors of the study have proposed to ignore studies that address this issue (E32).

Regarding the 'reduction of devitalized tissue', only one study in the 'mixed nutritional supplements' subgroup (E425) evaluated this outcome. There was a significant decrease in the number of bandages in the experimental group compared to the control group, so it is inferred that it improves the general health of the PU with regards to exudate and presence of devitalized tissues. Also, two studies ${ }^{(23,25)}$ have analyzed the outcome "reduction of exudate" and found a significant reduction in the amount of exudate in three to nine weeks, respectively $(\mathrm{p}=0.012 ; \mathrm{p}<0.0001)$. One study ${ }^{(25)}$ found a significant reduction of necrotic tissue $(\mathrm{p}=0.001)$.

Prior to the preparation of this review, searches were conducted in order to identify other SR that addressed the ENT as a treatment for PU. Three were found, however these were not restricted to ENT, and/or did not perform extensive searches in databases, and/or had not been properly updated. The first review ${ }^{(16)}$ included eight studies that dated from 1971 to 1995 , the second ${ }^{(17)}$ had four from 1990 to 2002 , and the third ${ }^{(18)}$ had seven studies from 1971 to 2006. In this review ten studies published between 1971 to 2012 were included, of which five had more recent publication years to the other reviews.

In this review, the included studies were heterogeneous in relation to patients (surgical, residents of long term care facilities for the elderly - ILPIs, eligibility criteria), the type of intervention, sample and follow-up. It is inferred that the interpretation of the results of the studies should be done with caution given the sample size and follow-up losses. The heterogeneity between the studies prevented the combination and comparison of the results, and thus were considered inadequate to perform meta-analysis and to detect the effects of nutritional interventions.

Among the limitations of SR, RCT showed no adequate description of the methodology with relevant and clear information, meaning a detailed description of the methods of allocation concealment, random sequence generation, and use of a double-blind method. Similar to this review, a $\mathrm{SR}^{(25)}$ that evaluated the efficacy and safety of treatment strategies for adults with pressure ulcers published in 2013 included $11 \mathrm{RCTs}$, three of which were considered of good quality, two moderate quality and six of poor quality. To meet with the present review, limitations were reported as: low methodological quality; small samples, which limits the detection of statistically significant differences; differences in the population of patients according to the characteristics of ulcers (location and stage), and comparison interventions (placebo or standard treatment) ${ }^{(25)}$.

Another limitation was the risk of bias assessment, only two studies (E32, E90) had low risk of bias for all areas evaluated in the "Cochrane Collaboration tool for assessing the risk of bias in randomized clinical trials". The other RCT did not show adequate description of the methodology, such as a detailed description of the methods of allocation concealment, random sequence generation, and using double-blind method. However, it is not possible to precisely state that the absence of such data indicates that the study was not conducted properly; considering that sometimes data is omitted due to the rules of publication required by magazines such as a page limit for the study. RCTs included were conducted with small samples, a fact that complicates detecting the effects of interventions and significant differences between the groups.

The different components included in ENT: arginine (E5), vitamin C (E412, E419), hydrolyzed collagen (E32), OKG (E90), zinc sulfate (E418) and mixed nutritional supplements (E10; E424; E425; E426). Most of the studies had mixed nutritional supplements as an intervention which makes it impossible to check the effects of the components alone, or as a group for statistical analysis in the SR.

The studies differed with regard to data analysis, there were only graphs/charts and a lack of absolute data, obstructing the critical analysis and grouping of studies.

Thus, there is no way to confirm that ENT favors PU healing in adults and the elderly, but this review shows advances with a higher confidence index and less bias risk because only RCT were included, an extensive search in various database data was conducted, there was a strict and predefined methodology, relevant research was selected and critically-assessed, data was collected and analyzed from studies, providing important information for clinical decision-making.

\section{CONCLUSION}

From the individual studies, it appears that the ENT with protein and micronutrient formulas can provide benefits to the healing process as well as the calculation of the optimal dosage with regard to basal energy expenditure. However, there is insufficient evidence and meta-analysis was not possible to assert that ENT promotes PU healing. However, the importance of nutritional intervention in malnourished patients and those with PU is undeniable, done by the evaluation of multiprofessional staff and a specialized nutritional team. Thus, it cannot be determined which nutritional components should be adopted for treatment of PU until new RCTs are carried out. It is suggested that the clinical practice remains supported by the guidelines on PU and ENT treatment. 
Through this study, two gaps present in scientific production were found. The first was observed regarding the effectiveness of ENT with only vitamin $\mathrm{C}$ in the PU healing process, considering that the last RCT identified concerning this subject was from 1995. A second gap investigated concerns hydrolyzed collagen that although has shown favorable results and indicates that its action promotes PU healing, other studies that evaluated the effectiveness of supplementation for PU and other types of wounds were not found. Therefore, research that addresses the action of these two nutrients needs to be performed. Further research with a larger number of patients and with adequate methodology are necessary to obtain evidence to assess the impact of nutrition on ulcers.

Given the scarcity of data from quality RCTs to indicate the use of ENT and the composition of the formulas, it is appropriate to conduct new studies to be incorporated into this review in order to establish the safety, benefits and greater certainty regarding the use of ENT for treatment of PU. It is suggested to conduct randomized clinical trials with rigorous methodological description and sustained in concrete recommendations in the literature. They also need to be conducted with larger samples, an assessment of isolated nutritional components, with results described in detail and providing absolute data.

\section{RESUMO}

Objetivo: Avaliar a efetividade da terapia nutricional enteral no processo de cicatrização das úlceras por pressão em adultos e idosos. Método: Revisão sistemática cujos estudos foram identificados por meio das bases de dados Cochrane, MEDLINE/PubMed, SciELO, LILACS, EMBASE, CINAHL, Web of Science, e por busca manual. Incluíram-se ensaios clínicos randomizados, sem delimitação de período e idioma da publicação, que abordaram pacientes adultos e idosos portadores de úlceras por pressão, em tratamento comparativo entre terapia nutricional enteral e placebo ou entre terapia nutricional enteral com diferentes composições e dosagens. Resultados: Foram incluídos dez estudos, que contemplaram diferentes intervenções. Apontaram maior número de úlceras por pressão cicatrizadas nos grupos que receberam a intervenção. Os estudos incluídos foram heterogêneos em relação aos pacientes, ao tipo de intervenção, à amostra e ao tempo de seguimento, aspectos que inviabilizaram a metanálise. Conclusão: Embora a terapia nutricional enteral demonstre favorecer a cicatrização de úlcera por pressão, não foram encontradas evidências suficientes para confirmar essa hipótese.

\section{DESCRITORES}

Úlcera por Pressão; Terapia Nutricional; Cicatrização; Revisão.

\section{RESUMEN}

Objetivo: Evaluar la efectividad de la terapia de nutrición enteral en el proceso de cicatrización de las úlceras por presión en adultos y ancianos. Método: Revisión sistemática cuyos estudios fueron identificados por medio de las bases de datos Cochrane, MEDLINE/ PubMed, SciELO, LILACS, EMBASE, CINAHL, Web of Science, y por búsqueda manual. Se incluyeron ensayos clínicos randomizados, sin delimitación de período e idioma de la publicación, que abordaron a pacientes adultos y ancianos portadores de úlceras por presión, en tratamiento comparativo entre terapia de nutrición enteral y placebo o entre terapia de nutrición enteral con distintas composiciones y dosificaciones. Resultados: Fueron incluidos diez estudios, que contemplaron diferentes intervenciones. Señalaron mayor cantidad de úlceras por presión cicatrizadas en los grupos que recibieron la intervención. Los estudios incluidos fueron heterogéneos con relación a los pacientes, la clase de intervención, la muestra y el tiempo de seguimiento, y los aspectos que hicieron inviable el metanálisis. Conclusión: Aunque la terapia de nutrición enteral demuestre favorecer la cicatrización de la úlcera por presión, no se encontraron evidencias suficientes para confirmar dicha hipótesis.

\section{DESCRIPTORES}

Úlcera por Presión; Terapia Nutricional; Cicatrización de Heridas; Revisión.

\section{REFERENCES}

1. European Pressure Ulcer Advisory Panel (EPUAP). National Pressure Ulcer Advisory Panel (NPUAP). Treatment of pressure ulcers: quick reference guide. Washington: National Pressure Ulcer Advisory Panel; 2009.

2. Dealey C. Cuidando de feridas: um guia para as enfermeiras. $3^{\mathrm{a}}$ ed. São Paulo: Atheneu; 2008.

3. Silva AJ, Pereira SM, Rodrigues A, Rocha AP, Varela J, Gomes LM, et al. Economic cost of treating pressure ulcers: a theoretical approach. Rev Esc Enferm USP [Internet]. 2013 [cited 2014 Jan 31];47(4):971-976. Available from: http://www.scielo.br/pdf/reeusp/v47n4/en_00806234-reeusp-47-4-0971.pdf

4. Guo S, Dipietro LA. Factors affecting wound healing. J Dent Res. 2010;89(3):219-29.

5. Brasil. Ministério da Saúde; Agência Nacional de Vigilância Sanitária. Resolução RDC n. 36, de 25 de Julho de 2013. Institui ações para a segurança do paciente em serviços de saúde e dá outras providências [Internet]. Brasília; 2013 [citado 2014 jan. 31]. Disponível em: http://bvsms.saude.gov.br/bvs/saudelegis/anvisa/2013/rdc0036_25_07_2013.html

6. Brasil. Ministério da Saúde; Agência Nacional de Vigilância Sanitária. Anexo 02: Protocolo para prevenção de úlcera por pressão [Internet]. 2010 [citado 2013 nov. 25]. Disponível em: http://www20.anvisa.gov.br/segurancadopaciente/

7. Shahin ES, Meijers JMM, Schols JMGA, Tannen A, Halfens RJ, Dassen T. The relationship between malnutrition parameters and pressure ulcers in hospitals and nursing homes. Nutrition. 2010;26(9):886-9.

8. Banks M, Bauer J, Graves N, Ash S. Malnutrition and pressure ulcer risk in adults in Australian health care facilities. Nutrition. 2010;26(9):896-901. 
9. Hengstermann S, Fischer A, Steinhagen-Thiessen E, Schulz RJ. Nutrition status and pressure ulcer: what we need for nutrition screening. JPEN J Parenter Enteral Nutr. 2007;31(4):288-94.

10. Thomas DR, Goode PS, Tarquine PH, Allman RM. Hospital acquired pressure ulcers and risk of death. J Am Geriatr Soc. 1996;44(12):1435-40.

11. Brasil. Ministério da Saúde; Agência Nacional de Vigilância Sanitária. Resolução RDC n. 63, de 6 de julho de 2000. Aprova regulamento técnico que fixa os requisitos mínimos exigidos para a terapia de nutrição enteral [Internet]. Brasília; 2000 [citado 2013 nov. 25]. http:// www.saude.mg.gov.br/images/documentos/RDC\%2063\%20NUTRICaO\%20ENTERAL.pdf

12. Brasil. Conselho Federal de Enfermagem (COFEN). Resolução n. 277, de 16 de junho 2003. Dispõe sobre o regulamento da terapia nutricional [Internet]. Brasília; 2003 [citado 2013 nov. 25]. Disponível em: http://www.cofen.gov.br/resoluo-cofen-2772003_4313.html

13. DiMaria-Ghalili RA, Bankhead R, Fisher AA, Kovacevich D, Resler R, Peggi A; American Society for Parenteral and Enteral. Nutrition Standards of Practice for Nutrition Support Nurses. Nutr Clin Pract. 2007;22(4):458-65.

14. Sherman AR, Barkley M. Nutrition and wound healing. J Wound Care. 2011;20(8):357-67.

15. Baxter YC. Critérios de decisão na seleção de dietas enterais. In: Waitzberg DL. Nutrição oral, enteral e parenteral na prática clínica. São Paulo: Atheneu, 2006. p. 659-76.

16. Langer G, Schloemer G, Knerr A, Kuss O, Behrens J. Nutritional interventions for preventing and treating pressure ulcers. Cochrane Database Syst Rev. 2003;(4):CD003216.

17. Stratton RJ, Ek AC, Engfer M, Moore Z, Rigby P, Wolfe R, et al. Enteral nutritional support in prevention and treatment of pressure ulcers: a systematic review and meta-analysis. Ageing Res Rev. 2005;4(3):422-450.

18. Reddy M, Gill SS, Rochon P.A. Treatment of pressure ulcers: a systematic review. JAMA. 2008;300(22):2647-62.

19. Sackett DL, Straus SE, Richardson WS, Rosenberg W, Haynes RB. Medicina baseada em evidências: prática e ensino. $2^{\mathrm{a}}$ ed. Porto Alegre: Artmed, 2003.

20. Higgins JPT, Green S, editors. Cochrane Handbook for Systematic Review of Interventions: version 5.1.0 [Internet]. Oxford: The Cochrane Library; 2011 [cited 2012 May 01]. Available from: http://www.cochrane-handbook.org/

21. Hulley SB, Cumming SR, Browner WS, Grady DG, Newman TB. Delineando a pesquisa clínica: uma abordagem epidemiológica. $3^{\text {a }}$ ed. Porto Alegre: Artmed; 2008.

22. Stocco JGD, Crozeta K, Taminato M, Danski MTR, Meier MJ. Evaluation of the mortality of neonates and children related to the use of central venous catheters: a systematic review. Acta Paul Enferm [Internet]. 2012 [cited 2014 Feb 18];25(1):90-5. Available from: http:// www.scielo.br/pdf/ape/v25n1/en_v25n1a16.pdf

23. Heyman H, Van De Looverbosch DEJ, Meijer EP, Schols JM. Benefits of an oral nutritional supplement on pressure ulcer healing in longterm care. J Wound Care. 2008;17(11):476-80.

24. Smith ME, Totten A, Hickam DH, Fu R, Wasson N, Rahman B, et al. Pressure ulcer treatment strategies: a systematic comparative effectiveness review. Ann Intern Med. 2013;159(1):39-50.

25. Frias Soriano LF, Vázquez ML, Maristany CPP, Xandri Graupera JM, Wouters-Wesseling W, Wagenaar L. The effectiveness of oral nutritional supplementation in the healing of pressure ulcers. J Wound Care. 2004;13(8):319-22.

26. Sociedade Brasileira de Nutrição Parenteral e Enteral; Associação Brasileira de Nutrologia; Sociedade Brasileira de Clínica Médica. Projeto Diretrizes. Terapia Nutricional para Portadores de Úlceras por Pressão. São Paulo: AMB; 2011.

27. Brewer S, Desneves K, Pearce L, Mills K, Dunn L, Brown D, et al. Effect of an arginine-containing nutritional supplement on pressure ulcer healing in community spinal patients. J Wound Care. 2010;19(7):311-6.

28. Wilkinson EAJ, Hawke C. Oral zinc for arterial and venous leg ulcers. Cochrane Database Syst Rev. 2012;(8):CD001273.

29. Bradbury S. Wound healing: is oral zinc supplementation beneficial? Wounds UK. 2006;2(1):54-61.

30. Coudray-Lucas C, Le Bever H, Cynober L, De Bandt JP, Carsin H. Ornithine [alpha]-ketoglutarate improves wound healing in severe burn patients: a prospective randomized double-blind trial versus isonitrogenous controls. Crit Care Med. 2000;28(6):1772-6. 